\title{
Paideusis
}

\section{Newman's Theory of Ideas}

\section{Leslie Armour}

Volume 3, Number 2, 1990

URI: https://id.erudit.org/iderudit/1073396ar

DOI: https://doi.org/10.7202/1073396ar

See table of contents

Publisher(s)

Canadian Philosophy of Education Society

ISSN

0838-4517 (print)

1916-0348 (digital)

Explore this journal

Cite this article

Armour, L. (1990). Newman's Theory of Ideas. Paideusis, 3(2), 3-16.

https://doi.org/10.7202/1073396ar

(C) Leslie Armour, 1990

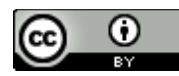

This document is protected by copyright law. Use of the services of Erudit (including reproduction) is subject to its terms and conditions, which can be viewed online.

https://apropos.erudit.org/en/users/policy-on-use/
This article is disseminated and preserved by Érudit.

Érudit is a non-profit inter-university consortium of the Université de Montréal, Université Laval, and the Université du Québec à Montréal. Its mission is to promote and disseminate research.

https://www.erudit.org/en/ 


\section{Newman's Theory of Ideas}

\section{Leslie Armour \\ University of Ottawa}

Newman was constantly concerned with the problem of knowledge and its relations to intellectual life. His explicit philosophy of education is laid down in his design for a university, but what he offers is implicitly an account of what the human being needs to know and to be in order to be fully human, and it contains, therefore, principles which should apply to the philosophy of education in general. When one seeks the principles, however, one seems at first sight mired in paradox. For Newman's philosophy is both liberal and conservative, bound by faith and devoted to reason, practically devoted to action and also deeply attached to leaming for its own sake.

It is to be understood, as George Tolley suggests, ${ }^{1}$ in terms of the themes which run through all of Newman's major writings. And yet the analysis of these themes only produces further paradoxes. I shall argue that the tensions tend to dissolve in a certain way if and only if one understands Newman's theory of ideas. This in itself is admittedly a vexed topic, but its main structure can be laid bare.

One may begin innocently enough: Tolley lists Newman's great themes as authority, responsibility, community, and commitment. These themes are connected--for authority is not the doctrine that force rules, but the denial of the doctrine that all opinions are equal and private. Authority, as Newman understood, demands notions of community, commitment and responsibility. Community, equally, is not for Newman an idea which entails the denial of individual responsibility, but the doctrine that individual responsibility can be and should be harnessed to a common end. Responsibility itself is not understood by Newman as associated with the view that each of us stands alone, but with the view that each of us has a part to play in the totality. Commitment is crucial to human dignity in Newman's view, for he holds that each person must take a stand, not just because there are moral issues to be faced, but because commitment--as Augustine insists--is an ingredient in truth as well as in morals.

If one thinks of Newman in terms of the common categories of social or political theory, the conflicts are obvious enough. But if one turns to educational theory, these conflicts cry out for attention.

The apparent liberals in educational theory must welcome Newman as one who supported liberal education in its traditional sense - - education which was intended to set men and women free, as opposed to education which equips each of them to fill a pre-determined social niche. ${ }^{2}$ His support of the tutorial system was not so much support of a system in use at Oxford--for Newman had many quarrels with Oxford dons over the question of how tutors ought to comport themselves--as support of a system of education in which the student participated constantly as a free being, and which above all was a system within which one's teacher was to be one's friend. No authority, per se, in Newman's view, could be allowed to come between tutor and pupil.

Conservatives, however, welcome Newman's insistence on the need for a constant attention to tradition and, indeed, he did invariably support the thesis that some tradition is always a necessary ingredient in any rational scheme of 
education. In a different sense of tradition, those whose affections remain captured by the images of the older British universities, welcome his distrust of the notion that universities should be dominated by research. Such an approach might seem to go with a defence of the humanities (including perhaps theology) as constituting somehow a superior kind of knowledge. Yet Newman strongly supported scientific research ${ }^{3}$ and in no way thought science an inferior kind of knowledge.

Part of the explanation, of course, is that universities have a different relation to teaching than they have to research. Newman knew that universities were not the only research institutions in the world and had good reason to suppose that they were not necessarily the best. There was and still is a strong European tendency toward the "academy system."4 But universities and other institutions with like aims were (and generally are) the only vehicles for a certain kind of education..$^{5}$ But Newman's views of research have, I shall argue, a deeper explanation in his view of the relations between a certain kind of research and a certain kind of education which he believed to be essential.

His view--perhaps the most central of his views--that education should centre on things worth knowing for their own sake, however, provides us with a hint that his educational theory is not likely to fit any standard mould. For both liberals and conservatives are inclined to suggest that learning must nearly always have an end beyond itself. The liberal, like Newman, wants to set people free and is, by implication at least, potentially a social reformer. Like John Stuart Mill, and unlike Newman, the liberal very often sees personal and social ends not as desirable by-products of the pursuit of knowledge, but as the chief end of that pursuit. The conservative's support of tradition suggests that there is an order to be maintained and that education ought to be its servant.

But Newman's notion that the knowledge to be most vigorously pursued is something worthwhile in itself needs exploration. For, again, his is not perhaps the most common version of this doctrine. Commonly, "knowledge for its own sake" is a doctrine offered in defence of the humanities. Not everything can be good for something else and much literature, the staple of humanities programmes, has to be regarded primarily as something valuable for its own sake. Poetry may move us to patriotism, charity, or even God, but it is a commonplace that it is not principally evaluated in these terms.

Newman, however, places theology, which tells us about God, literature, which, in his view, tells us about man, and science, which tells us about nature, on a par as basic human concerns. Each contributes to ends beyond itself and Newman does not deny this. But he would insist that theology does not, per se, save your soul, ${ }^{6}$ and literature does not necessarily bring about the selfrealization which occupied the idealist metaphysicians who were to dominate Oxford by the end of his life and career. ${ }^{7}$ He did not believe that science was primarily of value for the control of nature. ${ }^{8}$

Indeed, the thesis that knowledge is to be pursued for its own sake is always at the centre of his philosophy of education, but it is equally his view that the ends which people frequently hope to achieve through the pursuit of knowledge is pursued for its own sake. Indeed, if, as Newman thought, the best thing the human mind can do is to conform itself to the ways of God, then it must pursue truth for its own sake, for that is what God does. ${ }^{9}$

I shall argue that the tensions tend to dissolve in a certain way if one looks 
at Newman's theory of ideas. ${ }^{10}$ For it is this theory of ideas which carries Newman's account of knowledge in general, his basis for dealing with the rival claims of science and religion, and his way of dealing with his own pattern of religious beliefs.

Strictly speaking, however, Newman developed his theory of ideas to deal with what had always been the most continuously pressing problem in Christian theology--the problem of the development of doctrine. It was his answer to Roman Catholicism. It would not be surprising if it should turn out that this theory stemmed from his deepest intellectual convictions and if, once developed, it should have exercised a powerful influence on all his other concerms.

One must look at it, therefore, from two perspectives. One of them, its narrower perspective, is the problem in Christian theology. The other perspective involves both the function of Newman's answer to the problem of the development of doctrine--and so of traditions generally--in his dominant way of thinking, and its overall significance in his theory of knowledge. Since this theory of knowledge also entails a theory of the correct order of exposition and of leaming, it is equally his theory of education.

Let me begin with what is easiest, the exploration of the original theological context. The problem of the development of doctrine had always been a dominant problem of Christian theology for an obvious reason. The Church was compelled to hold that everything one needed for salvation had been known since the time of Christ, ${ }^{11}$ yet it was also compelled to go on applying and so developing its doctrine. One must not be blinded, however, by the theological setting. The situation is analogous to the one which applies in legal theory. Each time a contract is adjudicated, the concept of "contract" undergoes a real even if subtle change, for it now applies to a particular situation which gives concrete form to a general doctrine. The law can hardly admit that judges simply invent the law (though this has been suggested, of course), but it also cannot with a straight face pretend that nothing ever happens to it.

Newman's personal problem, however, was to be that the Church of England held that what was known in Christ's time by way of the necessities for salvation was all contained in Scripture. Article VI of the "Thirty-nine Articles" says "Holy Scripture containeth all things necessary to salvation" and Newman, when he was ordained, would have had to answer "yes" to the question: "Are you persuaded that the holy scriptures contain sufficiently all doctrine required of necessity for eternal salvation?" The reconciliation of this answer with his conscience was to haunt him for a long time. Chadwick reports that, as late as 1841 , Newman still thought that the introduction of any original doctrine was a heresy. ${ }^{12}$

One can see why anyone who took Christianity seriously would be troubled; for, though it would be natural to suppose that those who met Christ on earth had an advantage over those who came after, yet centuries of theology had produced a body of learning which could hardly be ignored and, in the course of it, successive church councils had crystallized doctrines in ways which, everyone would admit, would have come as a surprise to the first Christians.

Throughout the Reformation, this problem became, in one sense, the central issue. If the Church and its bureaucracy were to be challenged, its historical claim to possess title to whatever was "Christianity" had to be challenged, too. Hence, all the battles, at least superficially, were over what Chris- 
tianity originally was and over whether or not it should have developed at all. All sorts of fundamental issues--issues about the nature of authority, the relation of the clergy to the people, about morality and, perhaps most importantly, relations between church and state--took on a certain colouring from this dispute.

For Newman, I shall argue, this core became the central issue in his thinking about the nature of knowledge itself; for whatever knowledge is necessary for salvation must exhibit the hallmarks of knowledge, per se. Indeed, if there is such knowledge, it will be a kind of paradigm of knowledge.

Over time, between the beginning of the sixteenth and the end of the eighteenth century, it is true, the problem of the development of doctrine became subservient in most theological discussions to issues about conflicts of principle about particular doctrines.

By the end of the first quarter of the nineteenth century, however, the original problem had made its reappearance. Partly, this was caused by the development of historical knowledge; ${ }^{13}$ partly it was caused by developments in geology and biology; ${ }^{14}$ and partly, it was caused by the fact that the political battles of the day were being fought in the name of moral principles which were frequently thought to owe nothing obvious to traditional doctrine and so posed questions about the possibility of wholly new sources of knowledge which would compete with Christian doctrine. ${ }^{15}$ If there were such sources of knowledge and they were sound, would Christian doctrine become out of date?

Pressed with these questions, the response within the Church of England and amongst many non-Catholic Christians tended to concentrate along two general lines of thought, both of which Newman decisively rejected. One, which generally attracted the "evangelical" or "low church" wing of the Church of England, took the obvious form of simply denying that Christianity could change, and returning to a fairly narrow reading of the article of religion which declared the sufficiency of Scripture. Then, as now, this response attracted relatively little support in the universities, especially amongst scholars in the humanities who were familiar with the difficulties of establishing and interpreting the Scriptures in general and the Gospels in particular. The other response, which attracted many of Newman's friends and acquaintances, especially a group of reformers who centred around Thomas Amold, took the "broad church" view that Christianity must be compatible with whatever truth could be established. This must include moral truth. Moral discoveries were likely because society was becoming more sensitive to suffering. God and truth could not be separated and Christianity must respond. The problem of the reconceptualization of moral theory--the problem which Newman calls the development of Ethics ${ }^{16}$--was, I think, particularly important to him, with consequences which we shall see.

Official Catholicism took a third position: Christianity was hardly capable of "progress" and, indeed, new fundamental discoveries involving necessities for salvation were impossible. This meant that genuinely new moral truths were impossible, for one who failed to respond to genuine moral knowledge would, by definition, be risking his soul. Nevertheless, existing understandings could always be deepened, logical implications explored, doctrines which had been latent in the public belief and practice of the church could be formalized. These developmental issues were, of course, philosophical in kind, and, as the pressures produced by the nineteenth century grew, so did the apparent need for an 
official philosophy which would govern the process. This need was apparent to thinkers like Hyacinthe Gerdil ${ }^{17}$ even before the end of the eighteenth century. Cardinal Gerdil was a Malebranchiste philosopher--read carefully by Newman ${ }^{18}$--who was almost elected pope (his candidacy was vetoed at the last moment by the Emperor of Austria ${ }^{19}$ ). Had Gerdil been elected, a start would likely have been made on the creation of an official philosophy which would have been a kind of Neoplatonism tempered by Cartesianism. As it was, the issues dragged on through the century and, under Leo XIII, the Church opted in 1879 to go back to the period before the modern schisms and to adopt Thomism. ${ }^{20}$ The effect of this was, in official logic, to impose a very formal kind of Aristotelian deductivism from first premises on the system, in opposition to the more free-wheeling dialectics of the Neoplatonic traditions. This return to pre-modern traditions, especially to those of the high middle ages, evidently, made Newman uneasy. ${ }^{21}$

The Thomist view, at least as it was generally understood, permitted a certain notion of doctrinal development, but it suggested that what doctrine now contained should be deducible from what had always been present. Such a notion created many problems. Wide original definitions could make deductions easy, but honesty demanded restraint. The more usual response has always been (and continues to be) to rely on historical tradition as a source and to use the notion of development only as a kind of clarification. Thus, for instance, as recently as 1950 when the dogma of the bodily assumption of the Virgin Mary was proclaimed, it was argued that the faithful had always had such a belief in some form though it had never been completely codified or proclaimed as dogma. But how is one to establish that a new dogma really does have roots which go back to the beginning, and how, outside formal deduction, is one to find a procedure which will tell one whether a given doctrine does or does not conform closely enough to traditional belief? The answer in practice had to do with the historical continuity of the church as an institution and with the recognition of the validity of a long sequence of decisions, especially by church councils.

The problem, however, was particularly pressing in the Church of England as the nineteenth century neared its mid-point and it dominated the concerns of Newman and his associates in what came to be called the Oxford Movement. As a result of reaction against government intervention in the church, ${ }^{22}$ the Oxford Movement sought to disentangle to Church of England from the state and to give the church a basis for making its own claims. If neither the evangelical nor the broad church approach appeared satisfactory, the Catholic position seemed equally unlikely to help the movement's cause for the obvious reason that what the Church of England lacked was precisely the unquestioned continuity of the church as an institution.

In the end, Newman was to decide that doctrinal continuity and institutional continuity are inextricably bound together and this conclusion played the decisive role in his conversion to Roman Catholicism. But his intention when he set out to write the Development of Christian Doctrine was quite different. It was to provide a way of dealing with the development of doctrine which would depend on a different mode of reasoning. Basically, what Newman hoped to achieve was a theory of ideas which would be the basis of such a development. He lays down a notion of "real ideas" which develop over time but which do so 
by gradually revealing the aspects of the things which are their instantiations and through which their reality is expressed. He is not always crystal clear, but in one passage he does specify the fundamentals:

The idea which represents an object or supposed object is commensurate with the sum total of its possible aspects, however they may vary in the separate consciousness of individuals; and in proportion to the variety of aspects under which it presents itself to various minds is its force and depth, and the argument for its reality. Ordinarily an idea is not brought home to the intellect as objective except through this variety. ${ }^{23}$

This passage has sparked debate. George Tyrell drew the seemingly obvious conclusion that the "ideas" Newman was talking about were somehow objects: "... with Newman, 'idea' does not mean the mental formulation of an experienced object, but the object itself considered as apprehensible and intelligible." "24 But this makes for a doctrine which appears dark, indeed. The expression "the object considered as apprehensible and intelligible" is surely the idea either in a Platonic or Neoplatonic sense or in something like the Hegelian sense of the concrete universal. Jean Guitton adopts Tyrell's view throughout his book, ${ }^{25}$ although he adds that Newman does not always use the word "idea" in the same way. Owen Chadwick puts forward a more extreme (if not altogether clear) version of the "objectivist" view:

In this context, idea does not mean the notion which an individual may form of an object, but the object itself as it is capable of being apprehended in various notions. ${ }^{26}$

Against such readings, Edmond Benard ${ }^{27}$ suggests that the possible confusion between idea and object seems a serious obstacle to any reasonable reading of Newman's thesis about ideas. He argues that this "unnecessarily complicates" Newman's thought. He insists on the elements in Newman's definition of ideas which locate ideas somehow in the knowing mind. He says, "there is not a single instance in all of Newman so far as we have been able to discover which, upon a careful reading, gives any excuse for believing that Newman's "idea' was the thing itself as it exists outside the mind." 28

One might well respond "quite so"'; for, evidently, though there is good reason to suspect confusion, or, at least, to suspect that Chadwick (amongst others) has not clarified the notion of "object" there is a sense in which both readings of Newman can at least be explained. Newman is talking about ideas in the sense of real entities which are intelligible, apprehensible, and are instantiated in their objects. The difficulty is, surely, that the various aspects of the thing do not necessarily--and sometimes cannot possibly--exist all at once. As Tyrell says, ideas are not simply entities "in the mind." The mind is confined to certain moments of time as well. But the idea is not, as Benard says, "the thing itself' either. For the thing itself, whatever it is, cannot embody the whole scope of the idea. The thing might be a sliver of steel, but "what it is" involves its potentiality as well as its actuality. In any case, we now know that, if you were to stop the world dead at a moment of time, much of that sliver of steel would simply not be there, for not all its fundamental particles are continuous entities. So, too, with people: To know what a man or a woman is requires patient observation over a span of time. "Character" is not apparent in a flash of a second. A human life takes its meaning from a long process of development. 
Part of the issue is, indeed, about the sense of a very confusing word: "object." In one sense of "object," the object is what is sought--" the object of his quest," "the object of his life." The sense of "subject" which is correlative to this sense of "object" is not "subject" as it figures in "subjectivity" but as it figures in "subject matter." Both may be the thing in itself, but they have different relations to the searcher. But corresponding to the "subject" in "subjectivity," there is the "object" of "objectivity," something which is "just there" whether we think about it or not. For Newman, nothing is "just there" in any simple sense, for to be some particular thing is always to be an instance of an idea. The instances of the idea of the world are for him the development of the world which is the unfolding of the mind of God. But theology need not come into the story unless it is specifically a theological story, for the ideas are so far as we are concerned, "objective" in the other sense: They exhibit objectivity. The world is not the work of our whims.

This may sound unduly puzzling. But, when we speak of the house across the street and want to talk of the "object itself" as opposed to our idea of it, we mean by the object itself whatever is the correct interpretation of what is presented. We have in mind whatever it is which puts an end to our quest.

Newman's thesis is that the fully developed idea is the correct interpretation. When we have "developed" our idea of the house so that we have that interpretation, then we say, quite properly, "what I have in mind is the object itself." Like the adequate ideas of Spinoza, the fully developed ideas of Newman (if there are any, for, in fact, it may be that all our ideas are subject to development) do not diverge from their objects.

To explicate all this, we must see Newman in his intellectual context. He was an admirer of Locke and had more than a passing acquaintance with modern philosophy, but he determined, in fact, to rescue the idea of idea from those of its modern entanglements which had seemingly given it a subjective twist, and to do so by returning in some measure to the era of the Church Fathers and to a kind of Christian Neoplatonism. Descartes and Locke both took ideas to be simply what the mind confronts. But it was an easy move from there to the quite different notion that an idea is the subjective content of the mind.

One must insist that Newman really does start with Locke and that he never contradicts Locke's account of ideas--at least as Locke finally explained them in his posthumously published Remarks Upon Some of Mr. Norris's Books. 29 Locke's ideas were meant to be transparent: one uses them to grasp objects; they are not objects of knowledge in and of themselves. Yet John Norris was constantly annoyed that Locke refused to explain in his Essay on Human Understanding just what an idea was. It was Locke's contention that one cannot say what an idea is if saying what it is is to give it a status as a kind of thing. One can only say what it is an idea of. What it is to be a material object is to be the correct interpretation of an idea. So to be a mind is to be the correct interpretation of another idea. To say what an idea itself is is not to interpret ideas. It is ideas which enable us to understand things. If we could say what ideas were and their existence was basic to reality, then we would have to say that only ideas exist.

In contemporary terms, we can understand part of this by analogy with the problem of seeing photons. Since photons enable us to see other things, if we could see photons we could not see anything else. Of course, photons can be 
known in some other way, but not by direct acquaintance. Ideas similarly can be known indirectly--through their interpretations. They have correct or incorrect interpretations, but they are exhausted by the totality of their possible interpretations just as a word is not something over and above all its meanings. We can know how words work, but a word is not a special kind of thing. It is, though, expressed through various kinds of things. In one sense it is a pattern of sounds or writing on paper. In another, perhaps, it is a mental state. One can, of course, say how words are expressed in sounds or in writings and one can say analogous things about ideas.

Newman was a serious admirer of Locke, ${ }^{30}$ and I think he took the Lockean view of the interpretability and the transparency of the idea almost for granted. But Newman does go beyond Locke's account. He does so in a way which carries us back to some of the Cambridge Platonists who influenced both him and Locke. Yet his view remains consistent with Locke's most basic convictions: ideas, indeed, have a plurality of structure in two senses. One of them is created by the fact that they must be expressed at some time and in some place to someone. The other structure is created by the plurality of possible interpretations.

Ideas begin as something which marks out a specific occasion. Such specific occasions are always dominated by their immediate appearances. The idea of the Incarnation may originally have been dominated by its expression through the personality of Jesus, by the socio-political conditions of the time, and by its context in the Jewish tradition. It is a long way from these elements to the complex doctrines contained in the manuals of Canon Law or to the late nineteenth century interpretations of the Canon Law. But this transition can be justified--at any rate as a possibility--because no idea is ever exhausted by any one appearance of it or by any one interpretation. These developments are brought about by the development of events. Thus, it has taken two millennia for us even to begin to grasp all the latent possibilities in the Christian message.

But different ideas develop in different ways and the idea of development itself must also be explored. Newman lists mathematical, physical, material, political, logical, historical, ethical, and metaphysical developments as examples. ${ }^{31}$ It is important to notice some of the distinctions and to dwell for a moment on what he says about ethical ideas.

Mathematical developments are the working out of rules in a game and do not show what Newman thinks to be development in its more interesting sense. In a curious way, Newman thinks, the development of an animal or a vegetable is simply the working out of the plan already contained within the thing. Our idea of the vegetable may develop as the vegetable itself develops, but the vegetable more nearly unfolds than develops. Material developments--such as the working out of the possibilities for irrigation canals in India--exhibit development in another sense, but again, bring to light what is implicit. Historical developments, by which Newman means things like legal precedents, come closer to the notion of development which he is seeking. When a precedent is applied, it not only brings a new case within its scope but, by doing so, changes--even if ever so slightly--the meaning of the rule. Political developments, he says, show even more sign of being real developments, for they inject new events, but they do so capriciously, while logical developments, by refusing all caprice, fall back almost to the level of mathematical developments. In their 
most extreme form, mathematical developments became metaphysical, a term which Newman uses, curiously to the contemporary ear, for strict "Aristotelian" deduction, "mere analysis of the idea contemplated." 32

It is really ethical development which gives us the clue to what he wants to say.

Ethical developments are not properly a matter for argument and controversy, but are natural and personal, substituting what is congruous, desirable, pious, appropriate generous, for strictly logical inference .... As certain objects excite certain emotions and sentiments, so do sentiments imply objects and duties. Thus conscience, the existence of which we cannot deny, is a proof of the doctrine of a Moral Governor .... That is, the doctrine of a Judge and Judgement ... is a development of the phenomenon of conscience ... and so again the social principle, which is innate in us, gives a divine sanction to society and to civil government."

"Development" " here, is a notion which involves both the working out of what is latent in an idea and its integration with other ideas so as to make a coherent intelligible whole. The passage is worth some analysis.

What happens is that we are confronted with what can be called a moral experience. It is, as Newman says, personal. By that, he does not mean, evidently, that it is subjective, but that it involves the activity of the person who is confronted. It is not a mere logical situation, such as one might face in mathematics, for, no doubt, some action is required.

The concepts which are involved are various. Newman's list includes congruity, desirableness, piety, appropriateness, and generosity. If one thinks of it, one can see how "development" of one's moral idea might take place as one's thinking unravelled. Something is desirable if it has the potential for being desired. An action which no one could desire for whatever reason (and presumably an action whose outcome no one could desire under any circumstances) could hardly be a moral action, for it would be an action which no one could recommend to another as something which he wanted to see done. Congruence meshes with this notion, for congruent here is probably being used in the sense in which, when it is used of persons, means agreeing in action with others. $^{34}$ Newman has in mind a kind of mild Kantianism which suggests that what one recommends to oneself one should be able to recommend to others in the same circumstances. Without some such notion, morality would lose the generality which alone permits the concept to do any logical work. For otherwise, what applied in one instance would not apply in the next like one, and morality must be something more than simple descriptions of particular acts. Appropriateness has to do with the measured matching of the response to the challenge. If one is asked to help a drowning person, it does not usually do to stop to check one's blood pressure, though it might be appropriate for some people on some occasions to do so. When one is asked to contribute to a plan to save an ancient Cathedral, a gift of a penny is appropriate from a child but not from a millionaire. Generosity is perhaps what distinguishes morality from mere legality. An ungenerous act may meet all the other requirements, but would we call it moral? Piety can be left aside for just a moment.

Newman's list is interesting because it enables one to see how morality is shaped by various distinct concepts, but one can see that one might want to add to or subtract from any such list. Still, the arguments tend to take a certain form. 
As the concepts unfold, the question always is, "Without this element, would the concept turn into another which we already have (morality into legality, for instance), or would it fail to enable us to respond to the situation?"

Newman claims here that moral situations excite emotions and that emotions, when they are encompassed in the right conceptual frame can be seen to imply duties and to impel us to one kind of action (moral action) rather than to another. In arousing the participation of the "person," moral situations arouse what Newman calls "conscience." Conscience, in this sense, is not, of course, a voice which tells us with certainty and precision what to do--for Newman denies that there is a voice with that kind of authority ${ }^{35}$--but a feeling of being bound to respond morally. This bond to morality is what he calls piety and it is this which he thinks (here anyway) to be the basis for belief in God.

Ideas, thus, lead us to interpretations which involve us in views of the world. They are localized in the affairs of particular persons in their original appearance, but as they develop they create public bonds. The "social principle which is innate in us" is not, of course, given by innate ideas. It is aroused in the process through which ideas generate consequences which involve us in the affairs of other people and in the creation of community, and is innate only in the sense that we have the capacity to respond morally and to form communities. If we are bound together in an ethical process, we are bound together in a process which sets us on a road at the end of which is the idea of perfection and, so, of God. Whatever Newman's God is, this is how she chooses to act in the world.

Now it is this process of development which creates tradition. Some tradition is inevitable. We may shrug off our inherited traditions but, like Joyce's Irish bartender, we will find our dreams then filled with rival traditions (as H.C. Earwicker or Finnegan--or whatever his name really is--finds himself captured by Vico, Freud, and Bergson). For ideas are the essence of human mental life and ideas generate traditions.

But the ways in which they do so give us the insight we need into Newman's philosophy of education. Ideas of the appropriate kind work only by arousing the individual and so our educational process must always realize that an idea sets in train the working of minds one by one. This is the final justification of the tutorial system.

The process can only work by exposing a tradition, and so this is what education above all does: it allows us to move freely in the context of the widest and richest tradition which can be provided within the limitations of morality. Morality does involve piety, but it does so only in a personal context--i.e., only because it is part of what arouses the individual to appropriate and congruous action. Hence, though the tradition to be taught must encompass religion, Newman says flatly in his Idea of a University that he has "no intention of bringing into the argument the authority of the Church" in determining what a university ought to be. 36

Traditions in this sense, too, are always open on two fronts. One is located within the mind of an individual. The other is located amidst the ideas as yet imperfectly developed by that tradition.

Education frees by locating the individual exactly on the cutting edge of a tradition, and successful education locates the individual on the cutting edge of the best tradition. 
If, then, a university is essentially an educational institution, we can see why it should have some kinds of research functions and not others. It must always be involved with the cutting edge of a tradition and, indeed, in any world which we can envisage, it will no doubt stand at the cutting edge of several traditions. The past of those traditions, their particular openness to the futures, and their specific way of individuating themselves within the minds of students must always be a primary concern. The gathering of facts in the sense that these are necessary for an ongoing technological society is not always the function of a university. It is so when the facts to be gathered are essential for the integration of the technological process into the ongoing tradition.

The tradition has a unifying effect. In drawing on Newman's account of the development of ethical ideas, I suggested that such views inevitably become involved in descriptions of the world. Newman speaks of how conscience leads to God. But it is just as easy to show that both appropriateness and congruence, on which he insists, require some view about the facts of the case. No one can make good moral judgement without a sound view of the world. Ethics leads to science just as inevitably as it leads to theology.

But equally, science leads to ethics. We cannot know the world without changing it, a truth now more evident in physics than it was in Newman's day. And it is just as apparent in biology. Without knowing how we ought to change the world, we cannot justify any claim about how we ought to go about our search for knowledge.

Traditions unify, but they also exclude. Should we have only one tradition, or ought we to examine many?

We might think that, if we had Newman's Catholic university, we might want to confine our university to a single tradition, but Newman would not have made that supposition. For though he thought that there was only, finally, one viable tradition, that of Roman Catholic Christianity, he realized that any tradition had to prove its worth and that it would fail in this task unless it continued to make use of whatever could be made intelligible in all the available traditions and unless, indeed, it could see them in their own contexts and on their own merits. 37

\section{Notes}

${ }^{1}$ George Tolley, Meaning and Purpose in Higher Education: Essays Based Upon a Use of ldeas of John Henry Newman (Sheffield: Sheffield Polytechnic, 1975).

2The term "liberal" is always tricky in Newman's writings, but his lectures on the idea of a university are specifically devoted to the idea of a liberal education. He says its aim is the inculcation of habits of mind whose attributes are "freedom, equitableness, calmness, moderation, and wisdom" (The Idea of a University, Doubleday edition, New York: 1959, p. 129). Newman's lectures on university education were originally published in two sections--Discourses on University Education in 1853, and Lecrures and Essays on University Subjects, in 1858. All references which follow are to the Doubleday edition referred to in later notes as Idea. Newman is sometimes called the enemy of 
"liberalism" and, indeed, he does attack a doctrine by that name, for instance, in his Apologia Pro Vita Sua, third edition, 1886, reprinted (London: Oxford University Press, 1964), pp. 297-310. But this doctrine is essentially one which implies that one may believe what one pleases without regard for any objective truth. He calls this kind of liberalism "the anti-dogmatic principle" which to his Latinate mind meant the doctrine that there are no clear and justified teachings on anything. It is really the doctrine which in the seventeenth century was usually called "libertinism." Newman applied it especially to religious notions.

IIdea, Part I, pp. 8-9, says that a university is intended for the dissemination not the advancement of knowledge, but Part II, Chapters VII, IX, X clearly support scientific research.

${ }^{4}$ One thinks of such bodies as the Soviet Academy of Sciences, heir to a much older tradition, but the National Research Council in Canada and the Centre Nationale de la Recherche Scientifique in France are equally obvious examples. In the United States, and latterly in Canada, "think tanks" have tended to have strong ideological associations and to be grinders of axes, but this is because "objective" research was more deeply entrenched in the universities and because bodies like the National Research Council have tended to be burdened with specific missions laid down by govemment.

${ }^{5}$ The institutions in question were not then or now always called "universities." It is difficult to find a short definition, but the institutions Newman intends are those which propose an education which goes beyond the inculcation of useful information, and are concemed with the overall development of the person. One has to hedge because though, in Scotland, universities had "general education" amongst their concems, the English universities came to favour a narrower and more intense preparation of the student. But it continued to be accepted that Oxford and Cambridge produced men generally prepared to govern the country and the empire and not just men filled with a certain amount and kind of information. The dissenting academies which preceded the new wave of universities which emerged during Newman's lifetime had similar general aims. Newman's hope is to found an institution which, in its turn, goes beyond personal development to the development of an objective capacity for the appreciation of reality for its own sake.

"In fact, he says, theology "cannot tell us anything of Christianity at all." (See Idea, p. 411.)

${ }^{7}$ Newman does not deny that literature is personal and that it has many useful by-products, but he insists that literature has to be concemed with saying things that are worthy in their own right and that the literary form must always be appropriate to its object, not to the titillation or even the mental improvement of the reader. (See Idea, pp. 267-269.)

${ }^{8}$ Newman tends to think that science, in fact, is valuable for the expansion of the human mind more than for its control over nature. (See Idea, pp. 153-155.) But again, this is ambiguous in a sense because what he is arguing is that the mind must be made cognizant of nature in order to achieve its own potential. Thus, science is not to be undertaken for this mind-broadening purpose, for its very virtue is that, in pursuit of its own ends, it brings about an awareness of the nature of reality.

${ }^{9}$ This assumes, admittedly, that the Augustinian equation of God and truth--an equation which Newman never doubted--really holds. 
10 Newman's theory is chiefly expounded in The Development of Christian Doctrine, first published in 1851. In Newman's life, the book marked what I think is the central continuing element. Major changes were made to the third edition (1878) and incorporated in later editions. It is, thus, important for one concerned with Newman's philosophical theories, but it is also possible that the changes mask some elements which may be important with regard to Newman's conversion. References in this essay are to the sixth edition (London: Longmans, Green, 1891), published the year after Newman's death.

${ }^{11}$ See, for instance, E.J. Bicknell and H.J. Carpenter, $A$ Theological Introduction to the Thirty-nine Articles (London: Longmans, Green, second edition, 1925), for a detailed discussion of how this article has been interpreted.

${ }^{12}$ Owen Chadwick, From Boussuet to Newman, The Idea of Doctrinal Development (The Birkbeck Lectures) (Cambridge: Cambridge University Press, 1957), p. 120.

${ }^{13}$ The religious crisis over history did not come to a head until the publication in 1835-1836 of David Strauss's Das Leven Jesu, but the philosophies of history of Herder and Hegel both raised serious questions about the development of religious doctrine.

${ }^{14}$ Darwin was not yet on the scene, but Buffon had dropped vital hints and, in 1809, Lamarck had started the debate in earnest with Philosophie Zoologique.

${ }^{5} \mathrm{By}$ the end of the nineteenth century, of course, the idea of the "social gospel" would emerge, but in the early nineteenth century the anti-clerical turn of the French Revolution was most often thought to stem from enlightenment principles which were in competition with Christianity.

${ }^{16}$ Development, p. 47.

${ }^{17}$ Hyacinthe Sigismond Gerdil, 1718-1802.

${ }^{18}$ Newman quotes Gerdil three times in the Idea (see pp. 10, 205, and 430). They had much in common despite, I think, some differences of opinion about John Locke.

${ }^{19}$ The Emperor acted through Cardinal Herzan.

20 Once the choice had been made, the reasons for it tended to drop out of sight, but the intention seems to have been to go back to the period before modem philosophical divisions and to find the most complete synthesis of the Aristotelian and Platonic traditions in western thought. For reasons which are not wholly clear, it turned out to be the Aristotelian strands in St. Thomas's philosophy which were emphasized, and this bears on the problems which Newman encountered in trying to lay down a philosophy which was at once Catholic and neo-Platonist.

${ }^{21}$ After the publication of the encyclical of 1879 which recommended the philosophy of St. Thomas, Newman wrote (and may have sent) a letter to Leo XIII saying that the church should be "substantially one with the teaching of St. Athanasius, St. Augustine, St. Anselm, and St. Thomas as those great doctors in turn are one with each other." Seeing how they, in fact, disagree, it is not clear how this should be done, but one must note the predominance of thinkers with a Neoplatonist twist in Newman's list. The letter is quoted in Adrian J. Boekraad and Henry Tristram, The Argument From Conscience to the Existence of God, (Louvain: Nauwelaerts, 1961), p. 46. 
${ }^{22}$ The most talked about particular issue had to do with the consolidation of dioceses in Ireland. See S.L. Ollard, A Short History of the Oxford Movement (London and Oxford: Mowbray, 1983; originally published 1915), p. 22.

${ }^{23}$ Development, p. 34.

${ }^{24}$ Through Scylla and Charybdis; or, the Old Theology and the New, (London: Longmans, Green, 1907), p. 292.

${ }^{25}$ La philosophie de Newman, essai sur l'idée de développement (Paris: Boivin, 1913).

${ }^{26}$ Chadwick, op. cit., p. 149. $131 \mathrm{ff}$.

${ }^{27}$ A Preface to Newman's Theology (St. Louis: B. Herder, 1945), pp.

${ }^{28}$ Preface, p. 137.

29 London: J. Bettesworth for R. Franklin, 1720 (included in A Collection of several Pieces of Mr. John Locke, never before printed or not extant in his Works.)

${ }^{30}$ In the Grammar of Assent (New York: Doubleday, 1955; originally published in 1870), pp. 137-138, Newman apologises for having to criticise Locke on the matter of the degrees of assent. He says, "I have so high a respect both for the character and the ability of Locke ... and there is so much in his remarks upon reasoning and proof in which I fully concur."

${ }^{31}$ Development, pp. 41-54.

${ }^{32}$ Development, p. 52. Newman appears to follow Bishop Butler and to precede Matthew Amold in using "metaphysical" as essentially a term of abuse which does not always have a fixed meaning.

${ }^{33}$ Development, pp. 47-48.

${ }^{34}$ The O.E.D. says this sense is "rare," but notes that it was used by Tennyson in this way."

${ }^{35}$ See the long discussions in Boekraad and Tristram, op. cit., and numerous discussions in John H. Newman. The Philosophical Notebook, Edward J. Sillem and A.J. Boekraad, (eds.) (Louvain: Nauwelaerts, 1969-1970), two volumes. The actual text is in Volume II.

${ }^{36}$ Idea, p. 52.

${ }^{37}$ Idea, pp. 52-53. Newman speaks there, at length, of what is to be found in Protestant traditions. Choosing what traditions to attend to has become more complex, since the variety of cultures which scholarship has made in some sense

"available" to a contemporary North American or European teacher has surely increased since Newman's time, and the development of multicultural societies has made the issue urgent. But if $I$ am right in thinking that ethical ideas are central for Newman, then the question becomes whether as ethical ideas are developed in Newman's sense of developed, they tend to converge or to diverge. This question has not been explored in Newman's terms. 